Revista Iberoamericana, Vol. LXXIV, Núm. 225, Octubre-Diciembre 2008, 1019-1038

\title{
LIBERALISMO, PRAGA DO LITERÁRIO: O CONTO BRASILEIRO CONTEMPORÂNEO SOBRE TEMAS DE HOMOSSEXUALIDADE ${ }^{1}$
}

POR

KarL Posso

The University of Manchester

\section{A SituaÇão ACtual: TRIUNFO DOS PÊLOS}

Numa tentativa de descobrir novos talentos nesta área, no ano 2000, as Edições GLS, São Paulo, convidaram brasileiros a escrever contos sobre homossexualidade masculina e feminina, bissexualidade e transgénero. Foram submetidas a apreciação centenas de obras, das quais quinze foram seleccionadas para publicação, num volume que adoptou como título o da história vencedora, "Triunfo dos Pêlos" de Aretusa Von. De acordo com o tema da competição, a história vencedora, uma versão actual e sexualmenteexplícita de Orlando(1928)de Virgínia Woolf, explora apropriadamente todas as possíveis permutações das identidades sexuais: uma mulher, vítima de violência doméstica, acorda como homem e embarca numa odisseia sexual por São Paulo, que culmina com ela como um travesti masculino possuindo arrebatadamente o seu próprio marido. O enredo leve de Von dramatiza as teorias de Eve Kosofsky Sedgwick, Judith Butler e Lee Edelman, onde o corpo não pode mais funcionar como sinal de uma identidade ou género subjacente e naturalmente articulada: aqui, o corpo masculino do narrador-protagonista lembra-se e delicia-se com o seu passado

1 É necessário fazer uma distinção entre o uso do termo "liberalismo" aqui e no contexto político especificamente latino-americano. Embora tradicionalmente os liberais procurassem limitar o poder do estado e favorecer a liberdade para todos competirem nas eleições e no mercado aberto, na América Latina contemporânea "liberalismo" tornou-se num termo englobante que também significa a crença de que a intervenção do estado nas áreas da educação, saúde e assistência social é necessária porque a função fundamental do governo é garantir os direitos legais e democráticos do indivíduo: daí que satisfazer as necessidades materiais dos pobres é imperativo para eles poderem exercer as liberdades de que devem usufruir. Em contraste, na Europa, o termo "liberal” é hoje em dia usado muitas vezes coloquialmente, e não tanto no sentido estritamente político, para se referir a opiniões que defendem todas as liberdades do indivíduo e consequentemente a tolerância da diferença - o que os oponentes podem descartar como relativismo corrosivo. Em relação às questões levantadas pela narrativa homossexual contemporânea, liberalismo neste ensaio é usado neste último sentido mais lato. 
feminino. A história quebra a relação supostamente natural entre o corpo e o sexo, interferindo com a ideologia do género enquanto processo pelo qual um corpo é socialmente obrigado a ser determinado pela biologia. Mostra que "masculino" e "feminino" são clichés que os corpos são forçados a encarnarem da melhor maneira possível; daí que, a possibilidade de proibição, de marginalização e de repressão de sexualidades supostamente não naturais é totalmente proscrita por Von.

O volume Triunfo dos Pêlos abre assim com uma actuação do politicamente correcto que é irreverente e humorística; actuação essa, que a maior parte dos outros inexperientes autores na colecção, não consegue atingir. Contos como "Davi e Rachel” de Abbud, "O Gosto Amargo do Seu Corpo" de Wil Cabral, "Insólita Indulgência" de Eduardo Rasgah e "Sem Pressa, Sem Culpa, Sem Limites" de Lucas Traut, são todos relatos que tratam sem rodeios do reconhecimento de homo ou bissexualidade e da inesperada alegria da aceitação dentro da comunidade, na vigília duma epifania sexual. Ao contrário de anteriores escritores brasileiros tratando de experiências homossexuais - Silviano Santiago, Caio Fernando Abreu, João Gilberto Noll e João Silvério Trevisan - os escritores em Triunfo dos Pêlos parecem ter sido todos tingidos por pensamentos liberais anglo-americanos, com os seus incessantes pedidos de aceitação e de normalidade para a homossexualidade. Por mais felizes que as personagens gay e lésbicas sejam no fim das histórias, fica sempre a convicção de que a homossexualidade é uma desvantagem, embora uma a que se possam adaptar. O homossexual aqui designa-se gay e depois aprende a viver com o seu fardo, enquanto se alegra com a tolerância dos outros pela sua depravação; deve sempre ser concedida autorização para a sua integração na família social. ${ }^{2}$ Além disso, tal integração, nestes contos, está completamente dependente

2 É aqui necessário fazer um comentário sobre as diferenças históricas e discursivas entre os termos "homossexual" "gay". O termo "homossexual" vulgarizou-se através do trabalho do psiquiatra alemão Richard von Krafft-Ebing nos fins do século xix. O discurso patológico "inventou” o homossexual como sendo uma pessoa/identidade anormal ou doente; antes disso tinham apenas existido actos sexuais entre pessoas do mesmo sexo. É devido a esta raiz médica que o termo "homossexual" perdeu a sua popularidade no século xx. O uso do termo "gay" em relação a acções sexuais entre o mesmo sexo, que entrou na corrente anglo-americana durante os anos sessenta, derivou do desenvolvimento da conotação sexualizada das definições iniciais do adjectivo: "dado ao prazer" ou "sem preocupações”. "Gay” é em grande parte associado com auto-identificação, a luta contra a discriminação e o florescimento de uma sub-cultura, e daí as suas conotações mais positivas. Apesar das suas nuances originais, "homossexual” neste ensaio é usado no seu sentido mais lato significando uma pessoa orientada para o mesmo sexo, ao contrário de "gay" que tem conotações sócio-políticas e culturais mais imediatas. Neste ponto concordo com a convicção de Roberto Strongman de que parece mais neutro falar de "homossexualidades latino-americanas" do que de "identidades gay latino-americanas" porque estas últimas é são produtos do imperialismo cultural norte-americano. "Nevertheless, because of the current usage in Latin America of the U.S.-fabricated terms "gay", "lesbian(a)", "queer" to refer to some types of Latin American homosexualities - especially among 
dos homossexuais se tornarem, ou esperarem vir a tornar-se um casal; no Triunfo dos Pêlos, relações entre pessoas do mesmo sexo podem apenas aspirar a tornaremse uma cópia empobrecida da díade conjugal heterossexual. Para a maioria dos escritores desta antologia, o género só funciona dentro da matriz heterossexual de negação, identificação e melancolia e não explora as maneiras como os corpos podem relacionar-se diferentemente entre si.

Aliás, a marca do pensamento liberal anglo-americano nas histórias de Triunfo dos Pêlos é também revelada através do seu apelo a uma cultura da confissão: a auto-declaração é muitas vezes mostrada como um ataque de prevenção contra ser etiquetado pela hostilização de estranhos; a confissão transforma-se num perigoso acto de auto-libertação. Esta impulsão liberal levou por conseguinte a uma profusão de textos ensimesmados, cujo valor tende a ser de uma natureza "política" ou documental em vez de estética. Ou seja, enquanto que a literatura mais interessante joga com a expressão para amplificar e elaborar sobre as complexidades da experiência, convidando o leitor a abrir-se para o acontecimento do devir através do seu envolvimento com o texto, as histórias de Triunfo dos Pêlos são muitas vezes redutoras da experiência não heterossexual, elas dizem-nos tão afirmativamente quanto possível o que os indivíduos homossexuais supostamente devem ser. Há uma diferença fundamental, por exemplo, entre a homossexualidade como experiência numa história como a de Santiago "When I Fall in Love” ["Quando me Apaixono"], de Keith Jarrett no Blue Note (1996), e homossexualidade como identidade concreta em "O Gosto Amargo do seu Corpo" de Cabral.

Em "When I Fall in Love" o protagonista-narrador de Santiago visita o corpo do seu antigo amante num quarto de hospital e é ignorado pela mãe do morto; memórias e um jogo delirante de linguagem criam aqui um discurso indirecto-livre onde são dissolvidas histórias ostensivamenteprivadas. O conto deixa-nos com o arrombamento da subjectividade através do "você" pungentemente ambíguo da pergunta final: "Se você nunca soube quando tudo começou, como vai poder adivinhar como tudo vai terminar?” (147). O conto de Santiago entrega-se à perversidade e à complexidade da experiência - da experiência que é em parte homossexual - mas nunca se envolve directamente numa política identitária prescritiva. Nas suas histórias há actos ou ligações homossexuais, mas devido à falta de um discurso óbvio ou político, é difícil saber o que significa "ser homossexual", mesmo para os indivíduos envolvidos e isto resulta numa incerteza criativa: subjectividade como improvisação. O conto de Cabral, por outro lado, é reminiscente da literatura produzida por homens gay

the U.S.-influenced upper classes - I will be using those labels throughout the essay” (Strongman 177-178) [“Contudo, devido ao uso corrente na América Latina dos termos "gay”, "lésbica”, "queer" de fabrico norte-americano, para se referirem a certos tipos de homossexualidades latino-americanas - especialmente entre as classes superiores influenciadas pelos Estados Unidos - usarei estes termos no ensaio"]. 
britânicos ou norte-americanos nos anos setenta. Como defende Colm Tóibín, a literatura dessa década deu muitas vezes aos leitores gay "role models for use in the pursuit of the kinds of happiness that post-liberation gay life was meant to consist of" (24) [“modelos para serem usados na busca de tipos de felicidade que a vida gay após a libertação deveria consistir”]. De acordo com tal etos, o conto de Cabral termina com o seguinte diálogo e confissão (com o "você" aqui dirigido sem ambiguidade tanto ao protagonista como ao leitor):

-Oque vocêprecisa agora é sairmais, se assumir como gay, sair do armário, conhecer pessoas como você. Se você quiser, vou te levar pra conhecer uns lugares legais e umas pessoas interessantes. [...] Nunca vou me esquecer daquele final da década de 80, quando conheci o que era amor e tesão, amizade e traição. E quando aprendi a nunca mais esconder de ninguém quem eu era e o que sentia. (84-85)

OcontodeCabraléprescritivo: os homossexuais estão subjugados aumaimagem da sua própria identidade prevista e fixa. O seu conto articula-se numa "identidade gay” já constituída, que exige ser reconhecida para que o indivíduo “afectado" consiga atingir qualquer coisa semelhante a um estado de contentamento.

Uma outra diferença entre o trabalho de Cabral e seus colegas escritores e o de Santiago, é que com Santiago - ou Abreu, ou Noll - as personagens gay podem ter um fim trágico, como no caso de "When I Fall in Love" e do romance Stella Manhattan (1985); em Triunfo dos Pêlos isto não acontece por medo de vir a reforçar o mito do homossexual trágico, especialmente no seguimento das narrativas sobre a AIDS dos anos noventa. Enquanto que as histórias de Santiago elaboram sobre a constituição e a fragilidade de qualquer identidade ou ser, Cabral e os seus colegas escritores sacrificam nuance e preocupação estética a favor de objectivos políticos ou ideológicos: eles procuram articular os processos pelos quais as personagens gay e lésbicas funcionam, ou devem funcionar, em todos os aspectos da sua vida diária. Não que uma tal função política não tenha valor ou importância, porque embora a experiência homossexual possa ser extremamente individualista, enquanto a sociedade desdenhar os homossexuais como um grupo, continuam a ser necessários um sentimento de comunidade e a representação política colectiva. Mas há uma diferença entre uma literatura que procura promover um conjunto de crenças e que portanto aprecia a representação ideológica e o político sobre a estética, e a literatura que evita a aderência a preocupações especificamente políticas no processo de envolvimento com a criação de devires heteróclitos - e portanto não comunais.

As histórias de Triunfo dos Pêlos poderão ter contribuído para a criação de um crescente sentido de comunidade entre homossexuais masculinos e femininos no Brasil e ter até melhorado a visibilidade de uma série de questões na sociedade 
em geral, fundamentalmente a das relações entre o mesmo sexo e a necessidade de tolerância. Contudo, seria prudente refrear o entusiasmo destes escritores pela confrontação anglo-americana de identidades gay e lésbicas - identidades essas que oferecem ostensivamente oportunidades para intervenções políticas homossexuais - com as realidades do seu transplante para um contexto brasileiro. Como Santiago escreve no seu ensaio “O Homossexual Astucioso” (2000), a introdução do discurso anglo-americano sobre direitos gay em democracias emergentes como a do Brasil, produz às vezes incongruências sociais potencialmente devastadoras. O seu ensaio faz questão de salientar que as infra-estruturas éticas e políticas na América do Sul não são comparáveis com as da América do Norte, fazendo da primeira um terreno especialmente inóspito para formas de activismo gay beligerante. Santiago lembra claramente aqui os esforços do jornal Lampião (Rio de Janeiro), de curta duração, e dos movimentos de direitos gay - SOMOS (São Paulo), Adé Dudu (Bahia) - que no fim dos anos setenta, quando a ditadura militar começou a relaxar, lutaram para melhorar a situação de homens gay e de mulheres lésbicas no Brasil; os activistas envolvidos sofreram investigações policiais, humilhações públicas e intimidação (MacRae 219-240).

A situação na vizinha Argentina na altura era marcadamente pior. Ali, no seguimento da queda do General Onganía em 1971 e até o reino de terror que começou com o golpe militar de 1976, a Frente de Liberación Homosexual participou das campanhas revolucionárias de esquerda, enquanto sofria a indignidade de nem sequer ser publicamente reconhecida pelo Partido Socialista de los Trabajadores ou pelo ramo socialista da Juventud Peronista. O movimento FLH fomentou uma certa solidariedade entre os seus membros, criou um pequeno grau de consciencialização pública e participou da política revolucionária e no entanto, como conclui Néstor Perlongher: "En cuanto a sus resultados concretos, la experiencia del FLH argentino constituye, a todas luces, un fracaso. No consiguió imponer una sola de sus consignas, ni interesar a ningún sector trascendente en la problemática de la represión sexual, ni - tampoco - concientizar a la comunidad gay argentina” (83). Apesar do celebrado fervor activista de Perlongher, as suas conclusões sobre militância gay na Argentina nos anos setenta levam-nos de volta à prudência de Santiago e ao facto de que na América Latina pós-ditatorial, os grupos militantes lutam por igualdade, sem no entanto terem como objectivo nenhuma legislação explicitamente anti-homossexual. No Brasil, desde 1830 a repressão da homossexualidade tem sido grandemente dirigida pela conspiração de códigos religiosos e morais (Green 20-22). Por isso, apesar de corajosos esforços correntes de determinados grupos para educar a sociedade, através de iniciativas endossadas pelo governo, como o programa "Brasil sem Homofobia”, o país continua profundamente homofóbico 
- tendo a AIDS feito piorar a situação significativamente - e os homossexuais continuam a sofrer exclusão, discriminação e violência. ${ }^{3}$

Santiago também lamenta a mudança latino-americana para a estratégia da "saída do armário" norte-americana, que os escritores de Triunfo dos Pêlos abraçaram tão avidamente. Ele defende além disso que a adopção de um modelo exibicionista de política sexual, pelas chamadas culturas periféricas, é sintomático de um desejo de induzir modernização através de imitação - sem permitir o devido processo de aculturação e transformação gradual. Uma perspectiva partilhada pelo crítico Denilson Lopes, que em 2002, lamentou e receou que dentro de certos círculos do Brasil, "gay" tenha-se tornado uma etiqueta vulgar ou distintivo de moda, que já não implica nenhuma transformação social significativa: "cada vez mais o termo gay parece um item banal na nossa classe média com complexo de Miami ou de Nova York, propaladora de um consumismo desenfreado" (Lopes 31). Para Santiago, no entanto, tais impetuosas medidas de modernização podem ter efeitos piores do que a mera alimentação de um vago consumismo; ele defende que esta importação descuidada de identidades, etiquetas e imagens do Norte pode encorajar as tácticas antagonistas de desaforo gay em sociedades que não foram historicamente condicionadas para as acomodar. Mais uma vez o cerne da questão é o facto de que em nítido contraste com os Estados Unidos, onde muitos estados ainda têm leis contra a sodomia, as proibições constitucionais latino-americanas contra a homossexualidade são virtualmente inexistentes; o que normalmente é punido na América Latina não é o acto homossexual em si, mas a sua alegada divulgação na esfera pública como "indecência pública".

Santiago partilha portanto da opinião contenciosa de que o caminho confessional para a liberdade, defendido pelos activistas norte-americanos, pode ter efeitos calamitosos na América Latina, onde muitas "homossexualidades" nativas operam através de liberdades permitidas pelo segredo. Quanto a igualdades e direitos, ele mantém que a procura cega de direitos pode trazer resultados desastrosos, o que muitas vezes acontece, mesmo no seu ambiente "nativo" ocidental, onde pode levar à visibilidade sem protecção e à troca da liberdade do sigilo por uma maior vulnerabilidade. Ao contrário dos ideais norte americanos de libertação através da divulgação, Santiago defende a posição radicalmente diferente do homossexual que se recusa veementemente a ser vítima do armário ocidental, clamando injustiça, que não luta pelo direito a parcerias civis e que não tenta tornar-se um modelo para a integração social sem dor. Santiago admira o "homossexual astucioso", um jogador astucioso que tira o melhor partido da vida na margem. Isto será familiar

\footnotetext{
3 Ver a base de dados Grupo Gay da Bahia, disponível em <http://www.ggb.org.br>; também ver os ficheiros sobre Brasil no website International Lesbian and Gay Association, disponível em: <http:// ilga.org>
} 
para aqueles que conhecem a ficção de Santiago, em especial os contos de Keith Jarrett no Blue Note.

\section{PROMISCUIDADE NARRATIVA}

Voltando ao assunto da ficção e consequentemente ao cerne deste artigo, é necessário neste ponto salientar que tirando a questão importante da política, a razão principal pela qual a narrativa liberal da "saída do armário" é insatisfatória é simplesmente porque não gera boa literatura - a história é sempre essencialmente a mesma. E um escritor não se deve comprometer com uma narrativa específica; deve ser muito mais promíscuo: filtrando parcialmente o alheio pelo autóctone; tomando elementos da cultura e da ideologia globalizada e submetendo-os a escrutínio e revisão, debaixo de experiências locais ou pessoais ou de caprichos. Promiscuidade narrativa e ideológica portanto, não como uma hibridação igualitária idealizada mas como um correlativo da promiscuidade ética definida por Brad Epps em relação a Perlongher, na qual o que é valorizado é precisamente: "la ambivalencia o el vaivén; la resistencia a formulaciones tajantes y totalizantes; la falta de nitidez conceptual; la inadecuación para con dispositivos doctrinarios y dogmáticos (sea la que sea su procedencia política); y la aglomeración de lastres, cargas, consecuencias, dificultades y desventajas" (149).

Se o literário pode ser definido, pelo menos parcialmente, como aquilo que dá prazer textual através da sua ambiguidade sedutora, da sua resistência arreliadora, então textos que falam só transitivamente, que articulam de uma forma puramente indicativa sobre o trauma da "saída" ou da assunção de uma identidade marginal, excluem a possibilidade de uma leitura como actividade criativa e imaginativamente subjectiva. (É por esta razão que Maurice (1914) é o romance mais insípido de E. M. Forster). Em Triunfo dos Pêlos, Amanda, a protagonista de “GL?” de Ana Paula Grillo El-Jaick, vai ao cinema para ver um filme que acaba por ser tão mau como ela tinha previsto, mas este filme tinha-lhe parecido irresistível simplesmente porque o poster mostrava duas mulheres a beijarem-se. A qualidade artística desaparece porque o tema explícito homossexual chama uma certa audiência que precisa desesperadamente testemunhar algo que reflicta e consequentemente legitime os seus próprios desejos. Daí que os textos homossexuais auto-referentes de Triunfo dos Pêlos só podem servir para reforçar certos estereótipos do que os gays e as lésbicas são e fazem - e inevitavelmente portanto, com demasiada frequência acabam por ser objectivamente pornográficos.

Talvez a razão porque a escrita frontal destes jovens liberais pareça ser bastante pobre às vezes, quando comparada com a dos mestres da "escrita homossexual" no Brasil - Santiago, Abreu, Noll e Trevisan - é que, enquanto uma sociedade mais tolerante - quer esta seja real ou desejada - é evidentemente muito boa para gays 
e lésbicas, também pode se mostrar prejudicial no que diz respeito à literatura. Santiago, Abreu, Noll e Trevisan emergiram "quando as energias utópicas e rebeldes que agitaram os anos sessenta e parte dos setenta começam a perder força [e apareceram] paisagens entre a melancolia e a alegria possível, a deriva sexual e o temor da AIDS, a solidão e a ternura, a desterritorialização e a busca de novos tipos de relações” (Lopes 140). Eles emergiram numa altura de superativado fluxo ideológico e identitário, o que parece tê-los feito mais susceptíveis à introspecção existencialista e ao experimentalismo literário. Pelo contrário, os escritores em Triunfo dos Pêlos em geral parecem partilhar uma idéia muito mais clara do caminho para a felicidade: fora do armário e entre uma alternativa "família gay”. Como coparticipantes da competição da editora que levou à antologia, eles conseqüentemente comungam de uma noção muito clara de para quem escrevem - eles dirigem-se explicitamente a um nicho de leitores, uma coisa que escritores anteriores não tinham feito (pelo menos não de uma forma tão manifesta). A antologia é dirigida à nascente cultura brasileira "gay de consumo, que só atende aos interesses de uma classe média intelectualizada, pseudocosmopolita, [e que esconde] processos de exclusão brutais [...] pela proliferação de velhos e novos estereótipos” (Lopes 122). Também é importante salientar que outro fator aqui interveniente, em termos de evolução do estilo narrativo e de qualidade, é a sempre crescente exigência da literatura em geral ser prontamente acessível. Dentro de cada nicho, o texto precisa ser vendável ao maior número possível de leitores e, portanto este fator de acessibilidade-comerciabilidade desencoraja ativamente o que quer que seja que se aproxime de experimentação avant-garde ou complexidade filosófica. Quando se trata de mercantilização e disponibilidade da arte, a "literatura gay” não pode mais ser deixada fora do património capitalista.

Se, como sugere Roland Barthes em O Prazer do Texto (1973), o processo de interpretação da leitura não é uma questão de atribuir significado a um texto mas antes de compreender e apreciar os plurais que o constituem, então o papel do chamado marginal, neste caso os escritores e escritoras "gay", tem sido tradicionalmente de extraordinária importância para a literatura, precisamente porque a sua posição marginal na sociedade lhes permitiu ver e comentar de uma forma mais tangencial e portanto talvez de uma forma mais radical. Tomemos por exemplo “Linda, uma História Horrível” de Caio Fernando Abreu, de Os Dragões Não Conhecem o Paraíso (1988), a história de um homem gay nos estágios finais de doenças relacionadas com a AIDS, que regressa à casa para visitar a sua mãe, provavelmente pela última vez: a história é mais pungente por aquilo que ambos não dizem. Mostra que embora a arte e a literatura tratem de significados e de mensagens, o que lhes dá a sua qualidade artística e literária não é o seu conteúdo mas o seu afecto, no sentido deleuziano de uma força ou estilo sensível através do qual produz o conteúdo. 
Abreu faz-nos sentir o horror e a vergonha de ser marginal, ao deslocar afectos das suas origens reconhecidas e previstas: a casa da família como um local de terror reticente; o assalto de cheiros caseiros; a hostilidade e ferocidade de actos de caridade e de hospitalidade-a mãe empilha louça, oferece ao filho a sua antiga cama e beija-o para evitar olhá-lo e ouvir a sua "confissão" e consequentemente negar-lhe socorro. O medo e o terror não são mencionados no conto (para além do título), mas são afectos evocados pelo ritmo criado pelas pausas da mãe e do filho, calando, entre as trocas de banalidades e de memórias. Como mostra Abreu, o afecto, tal como é apresentado na arte, perturba as ligações quotidianas e opiniáticas entre palavras e experiência. Opiniões de todos os dias generalizam e reduzem conceitos às suas formas já conhecidas, sendo por conseguinte limitadoras porque assumem que há simplesmente um mundo comum a ser partilhado através da língua como informação e comunicação. Opinião de "senso comum" fala como se o mundo fosse facilmente traduzível para uma língua e experiência comum que todos nós partilhamos. Em "Linda, uma História Horrível”, Abreu desfaz a opinião de senso comum: a mãe não é maternal, a casa não é acolhedora e o triste e abandonado homossexual não é nem mais triste nem mais abandonado do que o mundo à volta dele.

Longe de condenação moralizante pelo tratamento do homossexual doente, Abreu oferece ao leitor uma ideia das forças que produzem tristeza humana: corpos que simplesmente não podem responder às percepções abertas por outras pessoas. Aqui, a desastrada linguagem, a insularidade e até as marcas e emaciação do corpo não são tanto características pessoais adicionadas à personagem do aflito doente de AIDS, mas mais ainda forças impessoais com as quais a sua personagem, a da mãe e até a da cadela Linda são efectuadas. Ninguém no conto consegue comunicar e até o sarcoma Kaposi do filho aparece camuflado contra o fundo de nódoas de nicotina e púrpura senil da mãe, as manchas de sarna da cadela, o carpete púrpura desbotado e as chávenas e paredes manchadas. O conto não se afasta dos horrores da AIDS, mas vai mais além, mostrando como toda a vida se atrofia quando falhamos em afirmar o seu poder para além do nosso ego específico, ou seja, o poder para incluir, criar e expandir relações. "Linda, uma História Horrível” é um conto acerca de um homem gay com AIDS, mas também é o diagnóstico de uma sociedade reprimida, cujos efeitos são a mãe e o seu filho; uma comunidade que se atrofia através da sua falta de vontade para desafiar o status quo e a sua moralização julgadora e que vai reforçando em vez de expandir os seus limites perceptíveis, diminuindo assim as forças da vida.

O conto de Abreu mostra desprezo pela sociedade e pelo normal, mas também faz pouco das absolvições purgativas da cultura gay anglo-americana, na medida em que a confissão longamente prevista do protagonista nunca acontece. Escritores como Abreu, e certamente aqueles antes dele, tiveram que ousar falar o nome do 
seu amor ou desejo clandestino com certa cautela, enquanto que os heterossexuais sempre assumiram e viveram os seus amores e desejos quase incondicionalmente; é precisamente por isso que os escritores gay têm estado, paradoxalmente, bem colocados para analisarem a anatomia da sociedade heterossexual e suas práticas. Tradicionalmente a escrita gay tem tido que lidar de uma forma inventiva com as ambiguidades e as complexidades da realidade; enquanto que os escritores e escritoras homossexuais hoje em dia reivindicam o seu direito a serem literais acerca do desejo pelo mesmo sexo e seus predicamentos e a sua ficção torna-se por isso mesmo mais pobre. Consequentemente, ao promover a especificidade como diferença e portanto ao assumir uma posição abertamente oposicionista em relação à heterossexualidade, estes escritores tornam-se muitas vezes ilegíveis para outros. Não só os contos de Triunfo dos Pêlos arriscam a manter em circulação estereótipos super simplificados de, por exemplo, o homossexual promíscuo ou o homossexual solitário, como também servem para perpetuar essencialismos suspeitos. Correm até o risco maior de colidirem com homofobia e reproduzirem esses efeitos de poder repressivo que a escrita e leitura gay deve tentar dissolver. Contudo, uma notável excepção vem do último conto da colecção.

O volume conclui com duas contribuições convidadas, a última das quais, "A Morte em Vida de Eustáquio Maria Boechat” de Alexandre Ribondi - um escritor reconhecidamente mais experiente do que os seus colegas contribuidores - brinca com a homossexualidade como um modus vivendi centrado no prazer e posiciona a relação com o outro como sendo acima de tudo uma teatralização, uma encenação e exercício do corpo masculino. O poeta epónimo visita uma poetisa muito mais velha do que ele, Ângela Selva, e sente-se dominado por comiseração e desprezo pela decana literária, num ambiente vagamente reminiscente de "Portrait of a Lady" ["Retrato de uma Senhora"] (1917) de T. S. Eliot. Selva é uma mulher desfeita: o marido dela suicidou-se depois do filho deles ter sido encontrado morto e violado. Num conjunto de circunstâncias improváveis, Boechat, que toma parte em vários encontros sexuais sem lustro, com a sua aluna Vera Xavier e com um velho amigo chamado Luciano Sobrinho, acaba por ter uma espécie de relação com um motorista de táxi, Geraldo Moura. Moura, fica-se a saber, tinha sido o amante do filho de Selva e Boechat acaba por descobrir que foi ele o seu assassino. O filho de Selva tinha insistido para que Moura deixasse a sua mulher, para eles poderem ficar juntos, mas é tal a aberração que Moura sente pela ideia de dois homens viverem como pseudo-casados, que se segue um violento apagamento do amante liberal. Boechat acha que com Moura ele nunca poderá ser capaz de declarar o seu amor, por isso a história acaba com a separação dos dois homens.

A figura traiçoeira de Moura parece ter sido tirada de Genet: embora a princípio ele pareça estar apenas restringido pelos imperativos deuma sociedade heterossexista, 
ele é claramente um homem que trai tudo e todos pelos requisitos dos seus prazeres solitários. A este respeito ele é surpreendentemente semelhante à gentil figura de Boechat. No começo da história, Boechat é uma figura passiva, cujas experiências sexuais são determinadas de maneira aleatória pelas oportunidades que surgem com as pessoas que cruzam o seu caminho. Ele vai para a cama tanto com homens como com mulheres, sem se preocupar muito com o assunto. Ao contrário dos outros protagonistas nesta antologia, não passa por uma crise existencial, no processo de busca pelo seu verdadeiro eu ou essência; ele apenas cede às reclamações corporais. Como diria Epps, seguindo Perlongher e Hocquenghem antes dele:

La promiscuidad, aunque siempre dada a mixturas, contradicciones y pluralidades, no ningunea la subjetividad en aras de una colectividad idealizada, pero tampoco necesariamente afianza o ensalza la subjetividad, ya que la abre, la expone y la hace vulnerable (especialmente con el paso de los años y el envejecimiento del cuerpo) justo en la medida en que la pone en circulación con una multiplicidad de cuerpos y sujetos. (149)

Nem Moura nem Boechat são meros receptáculos de normas e papéis sociais; são ambos pessoas profundamente determinadas - feitas e desfeitas - por sexo corporal. Ribondi dá ênfase à sexualidade dos corpos e fá-lo de uma maneira que contesta ambos os termos da distinção moderna entre sexo e género, uma distinção que reforça binários e hierarquias tradicionais. Para fazer sentido da noção de diferença sexual como acidental mas não arbitrária, será necessário prestar atenção ao conceito de essência. Sigo aqui de perto as explicações lúcidas oferecidas por Claire Colebrook no seu volume Gender (2004).

Segundo Aristóteles háa essência definida como sendo as propriedades principais ou características de uma coisa: o que faz de uma coisa aquilo que ela é; o poder ou potencial específico que a distingue. Para Ribondi o corpo é um poder, um potencial específico ou capacidade de vir a ser. Tal noção de essência é definida em oposição à tendência moderna para reduzir o que alguma coisa é às suas relações constituídas ou à sua maneira de ser conhecida. Podem muito bem existir poderes e potenciais, capacidades para esforço e transformação, que não estão ainda realizados em conhecimento eque podem ter uma força para interromper ou produzir conhecimentos. Neste sentido, essência não é apenas aquilo que permanece o mesmo - alguma propriedade estática que o pensamento pode simplesmente agarrar; mais propriamente, essência é o poder de vir a ser ou de se desdobrar de uma certa forma (Colebrook 236). Tal transformação ou força para devir será diferente dependendo dos outros poderes que vem a encontrar, mas não fica reduzida à sua já estabelecida relação com outros poderes. Isto é exemplificado por Boechat e Moura: eles mudam conforme as pessoas que encontram, mas quem eles são não é determinado ou "fixado" por quem 
eles foram, ou mais exactamente, por aqueles com quem eles tiveram relações sexuais no passado. É esta noção de essência que segundo Moira Gatens pode ser confrontada com a acusação moderna de essencialismo e de construtivismo moderno (25).

Podemos pensar em essência como a capacidade para produzir relações, com as relações diferindo de acordo com as capacidades e os poderes em questão. Em vez de um único conjunto de relações - digamos, as relações de linguagem, ou as relações legais - precisamos de considerar as relações entre mentes e corpos, as relações entre corpos, as relações entre linguagem, forças históricas, genética e ambiente. O pensamento seria colocado neste entrelaçamento de relações e não seria mais um ponto privilegiado, capaz de reduzir todas as relações a um sistema lógico abrangente (Colebrook 236). Neste caso, pensar em essência corporal seria pensar em algo que não pode ser reduzido a pensamento. Pensar em sexualidade essencialmente seria aceitar a ideia de que diferentes corpos podem-se relacionar diferentemente com o mundo. Uma essência real refere-se àquelas qualidades intrínsecas que dão a cada coisa a sua capacidade específica para se relacionar. Como Gatens e Lloyd defendem claramente: uma essência nominal é a maneira pela qual essas qualidades são conhecidas por nós, ou seja em termos de conhecimento, experiência e outros corpos (81-83). Daí que nunca podemos conhecer ou experimentar uma essência real; porque o que uma coisa é, em si mesmo, antes de qualquer relação, fica fora da relação do conhecimento e da experiência. Só conhecemos poderes intrínsecos ou potenciais nas nossas próprias relações e experiência. Isto significa que, as nossas essências nominais têm uma relação com a essência real, mas que esta relação varia ao longo da experiência: "Our thoughts, experiences and understandings of the world always proceed from and make sense of bodily experience; how could we have a world of spatial relations, others, a sense of identity, without some image of our own bodies?” (Colebrook 237) [“Os nossos pensamentos, experiências e compreensão do mundo provêm sempre da nossa experiência corporal e do nosso intento de torná-la compreensível; como é possível ter um mundo de relações espaciais, de outros, uma consciência de identidade, sem alguma imagem dos nossos próprios corpos?”].

Até que Boechat se torna consciente do seu próprio corpo e das suas necessidades, ele permanece potencial sem vida. O que Ribondi mostra no conto "A Morte em Vida de Eustáquio Maria Boechat” é que nós nunca conhecemos um corpo em si mesmo, mas apenas na sua forma vivida e imaginada. Como indica o caso de Moura, a diferença sexual não pode apenas ser vista como um efeito de ideologia social, como um acto de pensamento, em vez disso, os nossos pensamentos respondem, tornam compreensíveis e imaginam os nossos corpos sexuais: os corpos das personagens de Ribondi fazem muitas vezes exigências e o pensamento tem de as acompanhar numa tentativa de interpretar e compreender essas exigências. 
A ESCRITA, O CORPO E O DEVIR

Pode variar a maneira como imaginamos um corpo sexualmente diferente e nós só conhecemos e experimentamos o corpo através das suas relações vividas, mas isto não quer dizer que o corpo em si não tenha força antes da imaginação. O corpo sexual como poder ou potencial não é - como é para Judith Butler em Problemas de Género (1990) - um efeito que pode ser conhecido apenas na sua realização como género, porque o corpo tem poderes e potenciais que não podem ser reduzidos às normas já constituídas de género (Colebrook 238; Gatens e Lloyd 82). O corpo é sempre mais do que as imagens que nós temos dele e exigir reconhecimento deste corpo que se esforça afirmativamente é contestar a noção corrente da imagem como algo puramente mental e racional.

É irónico que o prefácio do Triunfo dos Pêlos, com o seu conjunto de escritores liberais, seja escrito por João Silvério Trevisan, um escritor que luta pelos direitos de gays e lésbicas em vários estudos sociológicos como Devassos no Paraíso (1986, 2000) e Seis Balas num Buraco Só (1998), mas cujos trabalhos ficcionais sobre temas gay evitam habilmente muitos dos enganos conceptuais discutidos acima. O seu conto "Dois Corpos que Caem” (1982), da colecção Troços e Destroços (1997), é uma ilustração esclarecedora de como o corpo sexual excede as imagens ou constrangimentos da razão. João e António, desconhecidos, encontram-se ao saltarem do famoso Edifício Itália no coração de São Paulo; eles começam a conversar a caminho do solo. João está a suicidar-se por razões amorosas, mas ele defende que este é um acto que reivindica o caos da vida contra a hegemonia da razão: a vivência racional tem a tendência de destruir o amor, ou seja, as paixões ou os "esforços positivos" dos corpos; por isso, num acto de rebelião, o seu corpo está a abraçar apaixonadamente o irracional ao saltar do edifício. Ele crê que este é um acto de desejo que a razão não vai ser capaz de pôr em ordem e que o seu corpo, portanto, demonstra o seu poder, o seu esforço para além da razão. Do mesmo modo, o suicídio de António é motivado pela descoberta de que "a razão tem demónios que a própria razão desconhece” (114). A razão não está equipada para lidar com a complexa e constantemente diferente realidade do corpo, por isso o suicídio é a única maneira de fazer coincidir a razão e a realidade corporal, embora, ele insista, de uma maneira irracionalmente finita. Ambos os homens estão a tentar ultrapassar o pensamento racional; no entanto, ironicamente, ao oferecerem explicações do que estão a fazer, os seus chamados actos irracionais são devolvidos ao âmbito da razão. Mas o problema é que ir "para além” da razão é sempre uma reacção à razão, o que dá portanto à razão uma posição primária; o facto é que o corpo sexual e os seus desejos "absurdos" aparecem antes da razão e a ultrapassam.

Mesmo antes de atingirem o solo, os dois corpos são enlevados por uma atraç̧ão mútua - algo que a razão não podia ter previsto e não pode explicar naquele instante. 
Os corpos ligam-se e depois morrem. João encontra o amor, ou descobre o potencial para amar, durante o seu suicídio "irracional”, quando fica também a saber que o amor em si nunca vai poder florescer. António faz coincidir na morte a razão e o corpo, mas esta correspondência bem sucedida vem no preciso momento em que o seu corpo lhe mostra que a natureza irracional do corpóreo é algo de precioso e que não se deve combater por a razão ser simplesmente inadequada. O conto de Trevisan sobre o suicídio duplo é um hino à vida e às maravilhas do imprevisível corpo sexual que excede sempre a razão. A questão da homossexualidade aqui surge como uma preocupação periférica - uma imposição taxionómica no fluxo imprevisível e incognoscível do desejo corporal. Dentro deste esquema de fluxo libidinoso não pode haver nenhuma relação "natural” limitada entre o corpo, o sexo e o género, por isso a ideologia de proibição de uma "sexualidade não natural" mostra-se absolutamente irracional. É isto que transforma esta história numa "escrita gay” verdadeiramente revolucionária.

Uma abordagem ainda mais interessante à homossexualidade, no contexto desta sexualidade involuntária dos corpos, pode ser encontrada no conto "Domingo Sem Néctar" de João Gilberto Noll, inicialmente incluído no volume $O$ Cego e a Dançarina (1980). Este éum gracioso esboço sobre um viajante solitário em direcção à casa dos seus sogros para ir buscar a sua mulher. Ele crê que ela se afastou depois da morte do filho deles, mas sem ele saber, ela tem uma relação extra-marital. O viajante pára numa estação de serviço; ele vai ao restaurante e pede uma cerveja. Enquanto bebe, é-nos oferecida uma montagem dos seus pensamentos que pssam da sua mulher e do seu desejo de a fazer feliz, para um jovem casal cansado com o seu bebé a chorar, à sua frente no restaurante, para uma sequência bastante lírica sobre a poderosa atracção entre uma abelha e uma flor amarela. Antes de sair, o viajante vai à casa de banho; enquanto urina vê à sua frente uma inscrição na parede - "anistia”, e imagina um homem na prisão limpando obsessivamente as unhas por tédio. Então um homem jovem aparece de pé a seu lado no urinol; o viajante nota sem compreender, que este homem é o prisioneiro que ele acabou de conjurar na sua mente:

O Viajante [...] não sabe se deve voltar o olhar para ele, talvez seja melhor fixar a visão na ANISTIA e imaginar a abelha rondando a flor, inspecionando o terreno da corola, suas jazidas do néctar que fabricará o mel - a abelha percebe que está num terreno de ricas promessas, reage com um frêmito no ar, as asas se convulsionam numa repentina alucinação, a flor relampeja o seu amarelo e o Viajante ali, olhando a ANISTIAe endurecendo o corpo como se prevendo alguma queda, o rapaz nota sem quer que o pênis do Viajante está quase totalmente intumescido mas não conserva o olhar porque enerva-se brutalmente e o se próprio pênis ganha um inesperado influxo, a mão do Viajante começa a arder em chamas e ele sente que uma náusea o salvaria, há alguns segundos os dois pênis já não urinam, estão ali, donos de si mesmos mas dominados por um impasse que não sabem de que. (769) 
Alguns momentos mais tarde o jovem desaparece no seu carro; o viajante assobia e pensa na mulher recomeçando a sua viagem; e a abelha, é-nos dito, recolhe o néctar da flor. Não nos são dadas quaisquer explicações ou conclusões.

O conto de Noll demonstra a capacidade essencial dos corpos sexuais para fazerem ligações de uma maneira que precede e é mais forte que o pensamento, de uma maneira que é de facto pré-subjectiva. Sorrindo beatificamente para o casal com o seu bebé no restaurante, o viajante pensa no amor pela sua mulher, apesar da falta de comunicação. Há os seus pensamentos de amor, de carinho e compreensão para com a sua mulher, mas o que ele precisa desesperadamente é da presença corporal dela para poder verificar esse amor. Há necessidade de haver um "erotismo inconsciente" dos corpos que não se baseie nem nas decisões de indivíduos em particular, nem nos projectos mútuos em que eles embarcaram, neste caso, o casamento (May 168). Uma ilustração chave deste ponto é dada pela abelha e pela flor. A abelha nas pétalas não está só a executar uma função biológica, ela liga-se à flor, explora-a, e ao fazê-lo, elas criam sensações que não são estritamente nem da abelha nem da flor. Não há possessão da atracção intensa entre a abelha e a flor e não há sujeitos envolvidos. A abelha e a flor são os objectos da atracção e não os seus sujeitos, mas elas não são os únicos objectos, também o são as asas, as pétalas, os estames, o movimento frenético, o cheiro do néctar e a cor amarela brilhante.

Olhando para o graffiti e concentrando-se na palavra hipnótica "anistia" - um perdão para todos, a suspensão da lei, dos regulamentos do dia a dia - dissolve os pensamentos deprisão do viajante, talvez uma metáfora para o marido cativo eacorda-o para a iminência da realidade corporal: assim, o prisioneiro imaginado está agora de pé a seu lado em carne e osso. Durante esta amnistia, o domínio do pensamento é interrompido e o corpo reina com impunidade. O viajante não tinha tomado a decisão de procurar um encontro homossexual, nem acha que o homem de pé junto dele é atraente. Ele não decidiu conscientemente fazer o que quer que seja desta situação: a sensação de queda, a mão escaldante e a erecção aconteceram todas automaticamente sem tomada de decisão. Do mesmo modo, a resposta do corpo do jovem à situação é também completamente involuntária. A maneira como os corpos destes homens se relacionam mostra como há sempre algo fora da nossa identificação como sujeitos e como pessoas. Ambos os homens se perdem num momento de comunicação sexual inexplicável: “dominados por um impasse que não sabem de que”. No erotismo do momento, já não há dois indivíduos e não porque agora haja um indivíduo que é a fusão dos dois. Não há menos indivíduos, há mais: há genitais, olhos, mãos. Há uma série de ligações e de experiências que surgem não como decisões, mas porque os indivíduos se perdem (May 168). No nível real e racional de seres discretos não há ligação física, não há contacto, não há consumação e consequentemente, de uma perspectiva objectiva e racional o dia continua a ser - eufemisticamente - um 
“domingo sem néctar”. Contudo, a um nível pré-subjectivo a história dos corpos é bastante diferente. Mais uma vez, etiquetar esta experiência de homossexual parece superficial ou impreciso, dado que género e obinómio hetero/homossexual se tornaram redundantes. Noll ilustra a contenda de Deleuze e Guattari:

Sexuality [...] is badly explained by the binary organization of the sexes, and just as badly by a bisexual organization within each sex. Sexuality brings into play too great a diversity of conjugated becomings; these are like $n$ sexes. [...] Sexuality is the production of a thousand sexes, which are so many uncontrollable becomings. (278)

[A sexualidade[...] estámal explicadapela organizaçãobinária dos sexos eigualmente mal explicada por uma organização bissexual em cada sexo. A sexualidade faz surgir demasiada diversidade de transformações conjugadas; estas são como $n$ sexos [...] A sexualidade é a produção de mil sexos, os quais são tantas transformações incontroláveis.]

O amor e a sexualidade são um assunto entre indivíduos, mas também são um assunto entre partes do corpo e superfícies que entram em contacto. Como descreve María Moreno em El fin del sexo y otras mentiras (2002): “[e]n la caricia no habría quién es quién, los bordes se atraviesan en una nebulosa táctil, la piel anestesiada por los besos ignora a su dueño [...] es insoportable como leer completo desde el principio al fin Paradiso de Lezama Lima (es mejor gozarlo por partes y salteado)" (20). Os indivíduos a quem essas superfícies ou partes pertencem são um produto desse contacto, assim como o seu sujeito. Isto é evidente no conto "Uma Casa no Campo" de Silviano Santiago em Histórias Mal Contadas (2005). Aqui, uma casa de campo cuidadosamente restaurada é o objectivo correlativo do amor entre o narrador e o seu falecido amante. Que a codificação social possa ter tornado este amor inaceitável é irrelevante para a história - o texto não pretende ser um panfleto dos direitos dos homossexuais. No que pode à primeira vista parecer uma passagem estranha, o narrador explica como a ideia de construírem juntos esta casa rural não tinha sido consequência de conversas racionais ou de decisões concretas:

Será que idéia tem dono? Será que, sem dono, ela pode ser presenteada? [...] Não se dá de presente uma idéia a um companheiro, comonão se dá de presente uma mamadeira a um bebê chorão. A idéia flutua no ambiente poluído pela convivência diária e amamenta dias e noites de conversas frustradas, de entendimentos equivocados, de subterfúgios camuflados e de horas insones. Dois corpos nus, silenciosos e solitários ficaram estirados na cama, desprovidos de cor e sentimentos próprios, à deriva das imagens coloridas na televisão sem som. Um dia [...] tomamos o café da manhã, dispostos a procurar uma casa no campo. (150) 
O narrador, o seu amante e a casa são objectos que surgem de - realizações de - uma virtualidade que a erótica do amor explora. A erótica explora a virtualidade a muitos níveis: o individual, o pré-individual, o entre-individuais, o entre as partes do individual. Neste caso, o evento de erotismo que surge através e entre as superfícies dos corpos do narrador e do seu amante cria tanto sujeitos como objectos, um dos quais é a casa. Isto não é simplesmente uma reformulação da ideia estereotipada do amor como intensidade transformadora, porque isto não é simplesmente uma interacção entre sujeitos individuais, mas uma "commingling [of subjects and objects] in a line of flight" ["mistura de sujeitos e objectos na mesma linha de voo"] (Flieger 43). O amor é tanto produto dos sujeitos e da casa como eles são do amor; a ideia da casa e a casa propriamente dita, são produtos do processo da transformação dos sujeitos, mas não uma decisão subjectiva nem dum nem doutro. No presente diegético são as sensações - o despertar - entre o corpo do narrador e a superfície dessa casa que incita o amor a prosseguir para além da morte física do amante; mas foi o amor que em primeiro lugar produziu o narrador, o amante e a casa.

Enquanto que os contos de Santiago e de Noll podem certamente ser classificados como "escrita gay", o seu poder literário baseia-se no facto de que, ao contrário da maioria dos contos em Triunfo dos Pêlos, eles lidam com essências - o poder de devir a ser - ao contrário de identidades rígidas, homossexuais ou outras. É também por esta razão que o "Triunfo dos Pêlos" de Aretusa Von é esclarecedor: o seu transsexual não apela nem para uma identidade biológica essencial, nem aceita o eu como uma simples construção cultural. Von mostra que para o transsexual é essência do próprio corpo e natureza desejar tornar-se outro diferente do que se é. Estes escritores subscrevem - embora sem o saberem - a uma concepção deleuziana de sexualidade em que os códigos sociais não diferenciam corpos que de outra maneira não teriam significado. As suas histórias ajudam-nos a compreender como começamos com uma multiplicidade de diferenças - linguísticas, genéticas, geográficas, hiper-diferenciações imperceptíveis de vida cujas regras de formação são demasiado finas para serem apanhadas na rede de abstracção binária - e como nós eventualmente temos dois sexos e duas sexualidades não porque a diferença seja imposta, mas porque a diferença é reduzida (Colebrook 221; Deleuze e Guattari, 260-265, 275-278; Massumi 92). A diferença é diminuída de todas as possíveis variações sexuais e genéticas para codificar os corpos no binário de feminino e masculino. Se, contudo, começarmos com a noção deleuziana de que há "milhares de sexos”, como Noll por exemplo faz em “Domingo Sem Néctar”, então poderemos pôr de parte o binómio_heterossexual/homossexual como sendo uma simplificação brutal e consequentemente evitar as questões e os discursos liberais de emancipação homossexual que repetirão vezes sem conta o próprio sistema heterossexista que tenta desmantelar, para além de intensificar a proliferação de narrativas quase indistinguíveis de "saída do armário" e de pedidos de tolerância. 
O melhor do conto brasileiro contemporâneo sobre temas de homossexualidade masculina, feminina e transgénero, ensinam-nos que reavaliar uma categoria nunca é suficiente: reivindicar a igualdade do homossexual com o heterossexual por exemplo, pode apenas tentar estabelecer um direito igual a privilégios e limitações do ortodoxo; assaltar e instalar-se na ordem existente poderá ser uma necessidade, mas, como afirma Brian Massumi, não é uma finalidade, porque fundamentalmente é um vir a ser o mesmo (123). Isto é em última instância, auto-destructivo a não ser que seja usado como um mecanismo protector, como um escudo político para um devir universal.

\section{BIBLIOGRAFIA}

Abreu, Caio Fernando. “Linda, uma História Horrível”. Os Dragões Não Conhecem o Paraíso [1988]. São Paulo: Companhia das Letras, 2001. 13-22.

Barthes, Roland. O Prazer do Texto [1973]. Jacó Guinsburg, trad. São Paulo: Perspectiva, 2002.

Butler, Judith. Problemas de Género: Feminismo e Subversão da Identidade [1990]. Renato Aguiar, trad. Rio de Janeiro: Civilização Brasileira, 2003.

Colebrook, Claire. Gender. Basingstoke: Palgrave Macmillan, 2004.

Deleuze, Gilles, eFélix Guattari.AThousand Plateaus: Capitalism and Schizophrenia. Brian Massumi, trad. Londres: The Athlone Press, 1996.

Edelman, Lee. Homographesis: Essays in Gay Literary and Cultural Theory. New York: Routledge, 1994.

Eliot, T. S. "Portrait of a Lady”. The Complete Poems and Plays of T. S. Eliot [1917]. Londres: Faber \& Faber, 1969. 18-21.

Epps, Brad. "La ética de la promiscuidad: reflexiones en torno a Néstor Perlongher”. Iberoamericana V/18 (2005): 145-162.

Flieger, Jerry Aline. "Becoming-Woman: Deleuze, Schreber and Molecular Identification”. Deleuze and Feminist Theory. Ian Buchanan e Claire Colebrook, eds. Edinburgh: Edinburgh UP, 2000. 38-63.

Forster, E. M. Maurice [1914]. Harmondsworth: Penguin, 1977.

Gatens, Moira. Imaginary Bodies: Ethics, Power and Corporeality. London: Routledge, 1996.

Gatens, Moira, e Genevieve Lloyd. Collective Imaginings: Spinoza, Past and Present. Londres: Routledge, 1999.

Green, James N. Beyond Carnival: Male Homosexuality in Twentieth-Century Brazil. Chicago: U of Chicago P, 1999.

Grupo Gay da Bahia <http://www.ggb.org.br>

International Lesbian and Gay Association <http://www.ilga.org> 
Lopes, Denílson. O Homem que Amava Rapazes e Outros Ensaios. Rio de Janeiro: Aeroplano, 2002.

MacRae, Edward. A Construção da Igualdade: Identidade Sexual e Política no Brasil da "Abertura". Campinas: Editora da UNICAMP, 1990.

Massumi, Brian. AUser's Guide to Capitalism and Schizophrenia: Deviations from Deleuze and Guattari. Cambridge: MIT P, 1993.

May, Todd. Gilles Deleuze: An Introduction. Cambridge: Cambridge UP, 2005.

Moreno, María. El fin del sexo y otras mentiras. Buenos Aires: Sudamericana, 2002.

Noll, João Gilberto. “Domingo Sem Néctar”. Romances e Contos Reunidos [1980]. São Paulo: Companhia das Letras, 1997. 767-769.

Perlongher, Néstor. "Historia del Frente de Liberación Homosexual de la Argentina”. Prosa plebeya: ensayos 1980-1992 [1985]. Christian Ferrer e Osvaldo Baigorria, eds. Buenos Aires: Colihue, 1997. 77-84.

Posso, Karl.Artful Seduction: Homosexuality and the Problematics of Exile. Oxford: Legenda/European Humanities Research Centre, 2003.

Santiago, Silviano. "O Homossexual Astucioso". O Cosmopolitismo do Pobre: Crítica Literária e Crítica Cultural [2000]. Belo Horizonte: Editora UFMG, 2004. 194-204.

Stella Manhattan [1985]. Rio de Janeiro: Rocco, 1999.

"Uma Casa no Campo". Histórias Mal Contadas: Contos. Rio de Janeiro: Rocco, 2005. 143-152.

"When I Fall in Love". Keith Jarrett no Blue Note: Improvisos de Jazz. Rio de Janeiro: Rocco, 1996. 119-147.

Sedgwick, Eve Kosofsky. Epistemology of the Closet. Berkeley: U of California P, 1990.

Strongman, Roberto. "Syncretic Religion and Dissident Sexualities". Queer Globalizations: Citizenship and the Afterlife of Colonialism. Arnaldo CruzMalavé e Martin F. Manalansan IV, eds. New York: New York UP, 2002. 176-192.

Tóibín, Colm. Love in a Dark Time: Gay Lives from Wilde to Almodóvar. Londres: Picador, 2003.

Trevisan, João Silvério. Devassos no Paraíso: A Homossexualidade no Brasil, da Colônia à Atualidade [1986]. Edição revista e ampliada. Rio de Janeiro: Record, 2000.

"Dois Corpos que Caem”. Troços e Destroços [1982]. Rio de Janeiro: Record, 1997. 113-116.

Seis Balas num Buraco Só: A Crise do Masculino. Rio de Janeiro: Record, 1998. 
Von, Aretusa e outros. Triunfo dos Pêlos e Outros Contos GLS. Prefácio de João Silvério Trevisan. São Paulo: Edições GLS/Editorial Summus, 2000.

Woolf, Virginia. Orlando: A Biography [1928]. Harmondsworth: Penguin, 1975. 